\title{
The Implementation of Islamic Teaching in Multiculturalism Society: A Case Study at Pesantren Schools in Indonesia
}

\author{
Muhammad Amri ${ }^{1}$, Saidna Zulfiqar Bin-Tahir ${ }^{2}$, Salman Ahmad ${ }^{3}$ \\ ${ }^{1}$ Alauddin Islamic State University of Makassar, Indonesia \\ ${ }^{2}$ English Education Department, University of Iqra Buru, Maluku, Indonesia \\ ${ }^{3}$ Alauddin Islamic State University of Makassar, Indonesia \\ Correspondence: Saidna Zulfiqar Bin Tahir, English Education Department, the University of Iqra Buru, Ambon, \\ Maluku, Indonesia. E-mail: saidnazulfiqar@gmail.com
}

Received: March 30, 2017

doi:10.5539/ass.v13n6p125
Accepted: May 12, $2017 \quad$ Online Published: May 31, 2017

URL: https://doi.org/10.5539/ass.v13n6p125

\begin{abstract}
The role of culture, ethnicity, race, belief and religious sects cannot be separated from the individual and social interaction and communication that often due to the conflict of thought and interest such in the political, social, and education. Thus, this study aimed at exploring how the implementation of Islamic teaching in a multiculturalism society at three of modern pesantren schools in Makassar, i.e. pesantren IMMIM, Pondok Madinah, and pesantren Darul Arqam Muhammadiyah Gombara. This study applied qualitative approach using a case study design by conducting the in-depth observation and interview to the teachers, stakeholders, and students. The data collecting were analyzed descriptively using three-stage models of Miles and Huberman. The results found that the pesantren educational policy, teaching methods, pesantren environment, stakeholders and teachers' control, and the evaluation were the dominant factors of the successful of Islamic teaching due to the strict of reward and punishment applied by pesantren to rehearse the students' awareness earlier to be well-behaved in a multiculturalism society.
\end{abstract}

Keywords: Implementation, Islamic teaching, multiculturalism, pesantren schools

\section{Introduction}

\subsection{Introduce the Problem}

Recently, the result of a study on how Islamic is Islamic countries conducted by Rehman and Askari (2010) has stirred up the Islam countries in the world especially in Indonesia. How could the result of this research have positioned Indonesia as one of the predominantly Muslim country ranks $140^{\text {th }}$ out of 208 countries? The result of this study certainly receives the positive and negative feedback from various countries who claimed to be the less Islamic country. On the other hand, this result was able to move some Islamic educational institutions in Indonesia to evaluate, redefine, and develop the Islamic education curriculum to be more Islamic.

The Islamic education is a teaching and learning process of formal and informal in order to form the learners who are able to actively apply the knowledge and skills based on the Islamic teachings (based on the Quran and the Sunnah of the Prophet Muhammad) to achieve a degree of humanity so as to fulfill the functions and responsibilities in prospering the earth and be able to realize the happiness in the world and hereafter (Azra, 1998: 5). If the Islamic education in accordance with what is stated by Azra, then the implementation of Islamic teachings during this time in Indonesia should be evaluated because there are many hindrances and obstacles faced so that the objective of Islamic education has not reached its goal potentially.

The Islamic education is now generally facing the challenges of modern life. Thus, it should be directed to the challenging need of modern society. To maintain the change, it needs a new paradigm of design to fulfill the new demands of the era. As stated by Kuhn (in HAR, Tilar, 1998: 245), when new challenges faced by using old paradigms then all efforts undertaken will meet with the failure. Therefore, the concept of Islamic education needs to be designed to answer the challenges of the era and constructing it to be relevant to the societal change.

The development of Islamic education formally in Indonesia is synonymous with the development of the pesantren schools whereby the Islamic teaching and learning process at the first time implemented at pesantren 
as the oldest educational institution and the direction for the national education. Pesantren or Islamic boarding school is an educational institution that has its roots in the Hindu-Islamic which was founded by Ki Hajar Dewantara as the indigenous education system in Indonesia since 1062 (Mastuhu, 1994; Fadjar, 1998; Yasmadi, 2002; Daulay, 2009; Madjid, 2013; Nizar, 2013; Engku \& Zubaidah, 2014: Bin-Tahir, 2015, 2017).

Currently, there are 27.218 pesantren schools in Indonesia including 240 pesantrens in Makassar (Depag, 2011). Pesantren students (santri) generally came from various provinces in Indonesia which have the different culture, ethnicity, race, language, belief, and religious sects such as Bugis, Makassar, Mandar, Palu, Kalimantan, Lombok, Maluku, Java, and Papua that made the pesantren schools' environment is very multicultural one. This diversity certainly gives the positive and negative impact on Islamic teaching and its outcome that could be explored from the students' attitude and behavior in their daily modern life.

A large number of pesantren schools and its students as well as its multiculturalism environment in Indonesia as a symbol of the application and output from the Islamic religious education that has not been identified by researchers in seeing how Islamic are the Islamic country in the Indonesian context. Based on the background, the researchers are interested in exploring the implementation of Islamic teaching and learning in pesantren schools in Makassar, Indonesia. The results of this study are expected to provide theoretical and practical contributions to the government and stakeholder to organize the Islamic education more Islamic and for the further researchers to measure and assess the impact of Islamic teaching and learning at pesantren schools quantitatively.

\subsection{Review of Literature}

The Islamic education has existed since the Prophet Muhammad was appointed as an apostle in Makah and him himself as a teacher. The education system at that time was the prototype that is continuously developed by Muslims for the benefit of the education. The Islamic education developed along with the emergence of Islam so Islamic education is a series of basic concepts that is always evolving indefinitely due to the existence of Islam in the world. Azra (1999: 5) defines Islamic education as the process of establishing individual character based on the Islamic teachings in order to achieve a high degree so as to perform the functions of the caliphate (Islamic leader) and successfully realize the happiness in both the world and the hereafter.

The purpose of Islamic religious education according to Daradjat et al. (2012) is underlined the three aspects, namely faith, science, and charity which basically contains: 1) Develop and establish a positive attitude, discipline and love towards religion in various life which might be expected human being devoted to Allah, obey the commands of Allah and His Messenger; 2) Obedience to Allah and His Messenger is an intrinsic motivation to the development of knowledge that must be possessed; 3) Cultivate and nurture the skills of religion in all fields of life and can appreciate the teachings of Islam in depth and comprehensive, so that, it can be used as a way of life, both in his relationship with Allah through worship vertically (persomal relatioan with God) or horizontally (personal relation to other people) reflected in morals deed as well as in his relationship with nature and the surrounding community through a good social interaction (Daradjat, et al., 2012: 89-90).

The glory of Islamic teachings not only arranging on the individual relationship with God but also an individual interaction with the surrounding community is the compulsory in very diverse cultures. Tilaar (2004: 82) defines multiculturalism as the institutionalization of cultural diversity which is owned by ethnic group within a nation-state through the fields or the legal system, education, government policies in health and housing, language, religious practice and the other fields.

According to Bank (2001: 128), the multicultural education is a concept idea or philosophy as a series of confidence (set of believe) and the explanation that recognizes and assesses the importance of cultural and ethnic diversity in shaping the lifestyle, social experience, personal identity, the educational opportunities of individuals, groups, and socials. Meanwhile, according to John Dewey (in Tilaar, 2004: 179), to define multicultural so he associates with democracy. In his view, multiculturalism is simply the recognition of cultural pluralism that is not a 'given' but it is a process of internalization of values in a community. The democracy is not just a procedural matter or form of government but a 'way of life' or as a weltanschauung of a community, then it is impossible to accomplish without the educational process.

The intercultural competence is one of the successful factors in teaching and learning in a multicultural classroom. The lack of teacher's intercultural competence is due to the misunderstanding and decreasing the students' interest in learning. Thus, a teacher must consider the students' cultural background in implementing an appropriate method and strategy in multiculturalism classroom (Bin-Tahir \& Rinantanti, 2016: 79). This study will explore the implementation of Islamic teaching and learning in multiculturalism classroom at pesantren schools. 


\section{Method}

This study employed a qualitative approach using case study design. 90 students, 10 Islamic teachers, and 9 stakeholders of the three pesantrens (pesantren IMMIM, pondok Madinah, and pesantren Darul Arqam Muhammadiyah Gombara) were purposively sampled as the informants. The following two criteria were used to choose the subjects: 1) they have lived in the pesantren for at least two years and 2) the teachers who teach Islamic religious. The study was conducted from September, 07th 2015 to November, 05th 2016 in Makassar, Indonesia.

The primary data collection instrument was the researchers themselves (Gay, Mills, \& Airasian, 2006) as the observer and the interviewer. It means that they decided what to be observed related to the problem statements. Then, they interpreted the data and confirmed the information about what has been observed by interviewing the students, the teachers, and the stakeholders. The secondary instruments were an observation scheme and an interview protocol. In collecting the data, the researchers employed three of the primary data collection techniques as follows:

\subsection{Observation}

The researchers as a nonparticipant observer or external observer were not directly involved in the situation that was being observed. The activities of observation were 1) the Islamic teaching and learning process in the classroom, 2) the students' activities outside the classroom, attitude, and behavior, and 3) the students' activity in the social interaction the community outside the pesantren. The researchers cross checked the data of the students' activities with the teachers and stakeholders. The researchers wrote the field notes on the activities and used a videotape to record the communication amongst the students and the teachers, which later was confirmed and adjusted to field notes.

\subsection{Interview}

In this study, the researchers interviewed the students, the teachers, and the stakeholders using the voice recorders. The type of the interview was the semi-structured interview in which some questions were prepared before interviewing and some additional questions were asked on the spot. The students and teachers' interview was used to collect the qualitative data or confirmation toward what had been observed.

\subsection{Documentation}

In addition to the observation and interviews, the data were also gathered through documentary evidence.

The data analysis began with the selection of all the data collected from the various sources such as interview, observation, and documentation. The procedure of data analysis coincided with the data collection process through a three-stage model, namely data display, data reduction, data presentation and verification. However, these three stages took place simultaneously. Checking the validity of the data in the study referred to the formulation of the research result which involved three things, namely (1) persistence of observation, (2) triangulation of data, and (3) referential adequacy. The validity of the data was tested with the relevant reference sources through books, documents, and activities of students" speaking (Kothari, 2004; Cohen, Lawrence, \& Keith, 2007).

\section{Results}

The data on the observation and interview results derived from the teaching and learning process in the classroom or outside the classroom and the students and teachers' activities inside or outside of the pesantren environment were analyzed descriptively. To facilitate the data presentation cumulatively, the researchers used the scale of 1 (very low), 2 (low), 3 (Good), and 4 (excellent). The symbols $(\sqrt{ })$ and (-) refer to the position of proficiency level scale.

\subsection{The Implementation of Islamic Teaching and Learning}

The Islamic teaching and learning at pesantren schools have varies strategies and methods to reach their goal whereby the vision and mission of pesantren are to graduate the students who have the competencies in Islamic study and technology that beneficial for himself and the society around him. It can be described in table 1 below: 
Table 1. Islamic Teaching and Learning at Pesantren

\begin{tabular}{lllllll}
\hline \multirow{2}{*}{ No Aspects } & & \multicolumn{3}{c}{ Existed } & \\
\cline { 3 - 5 } & & 1 & 2 & 3 & 4 & \\
\hline 1 & Vision and mission & - & - & - & $\sqrt{ }$ & Competence graduate in Islamic study and ICT \\
2 & Curriculum & - & - & - & $\sqrt{ }$ & Adopted three of curricula \\
& $-\quad$ Formal & - & - & - & $\sqrt{ }$ & 6 hours a day \\
& $-\quad$ Informal & - & - & $\sqrt{ }$ & - & 3 times a week \\
3 & Material & - & - & - & $\sqrt{ }$ & Appropriate \\
4 & Teachers' background & - & - & - & $\sqrt{ }$ & S2 and S3 graduate \\
5 & Methods & - & - & $\sqrt{ }$ & - & PPP, CL \\
6 & Facilities/Environment & - & - & - & $\sqrt{ }$ & Available/appropriate \\
7 & Controlling & - & - & - & $\sqrt{ }$ & Strict \\
8 & Evaluation & - & - & $\sqrt{ }$ & - & Per year \\
9 & Reward and punishment & - & - & - & $\sqrt{ }$ Strict \\
\hline
\end{tabular}

Table 1 shows that the vision and mission of schools are to improve the knowledge and skill competencies of graduates in the field of religion and information and communication technology (ICT) to be personally beneficial to the environment. It is supported by the complex curriculum which adopted three curricula, they are Kemendikbud (the ministry of education), Kemenag (the ministry of Islamic affairs), and Pesantren curriculum which would further enrich the knowledge and capabilities of graduates. In addition, the teachers in pesantren also have competent that can be seen from their background of study in which they were master and doctoral graduates and some of them were graduates of universities in the Middle East such Egypt, Sudan, and Saudi Arabia. Although the methods they employed did not vary but they can enhance students' knowledge. The boarding facilities also strongly support the application of knowledge that has been learned by the students where all students live in dormitories and supported also by the reward and punishment that is strict in controlling the activity of the students in attitude and behavior everyday life. This is consistent with the results of interviews with stakeholders (Top, Nas, Rid, and Her) which states:

"To achieve the vision and mission of pesantren schools, we are constantly working to improve the teachers' competence and school's facilities, to develop learning materials, to control the students and teachers' behavior by implementing a strict reward and punishment to train them to be consistency and inhabitation in Islamic behavior without distinguishing the ethnicity, race, and religious sects".

\subsection{The Implementation of Islamic teaching by the Teachers}

The implementation of Islamic learning in pesantren was more emphasizing on the role of the teacher as a role model to be emulated by the students, both in liveliness, discipline, and good manners. It can be seen in table 2 below.

Table 2. Teachers' Activity Inside and Outside the Classroom

\begin{tabular}{|c|c|c|c|c|c|c|c|c|c|}
\hline \multirow[t]{2}{*}{ No } & \multirow[t]{2}{*}{ Activities } & \multicolumn{4}{|c|}{ Inside the Classroom } & \multicolumn{4}{|c|}{ Outside the Classroom } \\
\hline & & 1 & 2 & 3 & 4 & 1 & 2 & 3 & 4 \\
\hline 1 & Active (teaching and controlling) & - & - & - & $\sqrt{ }$ & - & - & $\sqrt{ }$ & - \\
\hline 2 & Discipline & - & - & - & $\sqrt{ }$ & - & - & - & $\sqrt{ }$ \\
\hline 3 & Role model & - & - & - & $\sqrt{ }$ & - & - & - & $\sqrt{ }$ \\
\hline 4 & PPT Method & - & - & - & $\sqrt{ }$ & - & - & $\sqrt{ }$ & - \\
\hline 5 & Well-communicated & - & - & $\sqrt{ }$ & - & - & - & - & $\sqrt{ }$ \\
\hline 6 & Assertive & - & - & $\sqrt{ }$ & - & - & - & $\sqrt{ }$ & - \\
\hline 7 & Indiscriminate the others' culture & - & - & - & $\sqrt{ }$ & - & - & - & $\sqrt{ }$ \\
\hline 8 & Polite & - & - & $\sqrt{ }$ & - & - & - & - & $\sqrt{ }$ \\
\hline 9 & Friendly & - & - & $\sqrt{ }$ & - & - & - & - & $\sqrt{ }$ \\
\hline 10 & Tidy & - & - & - & $\sqrt{ }$ & - & - & - & $\sqrt{ }$ \\
\hline 11 & Clean & - & - & - & $\sqrt{ }$ & - & - & - & $\sqrt{ }$ \\
\hline
\end{tabular}


Table 2 shows that the teachers always make themselves as a role model for the students to behave based on Islamic teachings and be active, discipline, and indiscriminate people ethnicity or culture. So that the students are able to follow the teacher's behavior and accustomed to behaving polite and friendly to everyone regardless of their race and culture and always maintain the cleanliness and tidiness of their selves and the environment. As the expression of the teachers (Ham \& Az) below:

"Give an example to the students is a very effective lesson for them to be active and motivated to apply the Islamic teaching in their everyday life when the teacher is not as a role model, then the students will be lazy to learn and misbehaves in their social interaction".

\subsection{The Implementation of Islamic teaching by the Students}

The implementation of Islamic religious learning by the students inside or outside the classroom can be described in table 3 below.

Table 3. Students' Activity Inside and Outside the Classroom

\begin{tabular}{|c|c|c|c|c|c|c|c|c|c|}
\hline \multirow[t]{2}{*}{ No } & \multirow[t]{2}{*}{ Activities } & \multicolumn{4}{|c|}{ Inside the Classroom } & \multicolumn{4}{|c|}{ Outside the Classroom } \\
\hline & & 1 & 2 & 3 & 4 & 1 & 2 & 3 & 4 \\
\hline 1 & Active (learning and worship) & - & - & - & $\sqrt{ }$ & - & - & - & $\sqrt{ }$ \\
\hline 2 & Discipline & - & - & - & $\sqrt{ }$ & - & - & $\sqrt{ }$ & - \\
\hline 3 & Well-communicated & - & - & - & $\sqrt{ }$ & - & - & - & $\sqrt{ }$ \\
\hline 4 & Respect other people & - & - & - & $\sqrt{ }$ & - & - & $\sqrt{ }$ & - \\
\hline 5 & Indiscriminate the others' culture & - & - & - & $\sqrt{ }$ & - & - & - & $\sqrt{ }$ \\
\hline 6 & Polite & - & - & - & $\sqrt{ }$ & - & - & $\sqrt{ }$ & - \\
\hline 7 & Friendly & - & - & - & $\sqrt{ }$ & - & - & - & $\sqrt{ }$ \\
\hline 8 & Tidy & - & - & - & $\sqrt{ }$ & - & - & $\sqrt{ }$ & - \\
\hline 9 & Clean & - & - & - & $\sqrt{ }$ & - & - & - & $\sqrt{ }$ \\
\hline 10 & Reinforcement & - & - & - & $\sqrt{ }$ & - & - & $\sqrt{ }$ & - \\
\hline
\end{tabular}

Table 3 shows that the students actively apply the teachings of Islam that they have learned in their daily lives, both inside or outside the classroom. The discipline, respect the others, and politeness was highlighted in the formal learning in the classroom. While outside of the classroom, there were a small number (4\%) of students who were not disciplined and sometimes they quarrel among their peers, which were not caused by a culture diversity problem, but of misunderstanding in terms of discussion. They were very friendly inside or outside the classroom because they felt kinship and togetherness. As the statement of the students (HR, SR, ZA, and MA) below:

"We are all brothers because of kinship and togetherness at the hostel, away from parents, and equally speculate in the study, we are very compact in every aspect and mutual support between each other although sometimes there was a difference of opinion".

The tidy and clean were the main characteristic of pesantren students in which there were rewards and sanctions firmly so that students were accustomed to looking neat and clean inside or outside the classroom in accordance with the circumstances. Most of those who look less neat were caused by the unusual use of gloves and tie. As an expression of the students (AB, MH, and FS) below:

"We came from the village; we don't know how to wear the tie, and we are not used to tying so that we sometimes take it off when we were not supervised by teachers".

The data from the observations and interviews above shows that the students' liveliness, discipline, and other behavior inside or outside the pesantren were strongly influenced by the presence of reinforcement, either reward or punishment.

\section{Discussion}

Based on the above findings, there are some aspects and domains that should be underlined to in this section as follows:

The vision and mission of the three schools are to produce Islamic-minded learners who have the technological competence to be utilized for the local community regardless of race, ethnicity and religious sect, but to unify the 
differences and diversities between communities. This suggests that pesantren want to balance the relationship between religious adherent with God and the relationship between the religious adherent with the surrounding community that illustrated in the complexity of the Islamic teaching implementation, the three curricula, duration of learning, and PPP methods (presentation, practice, production) that is applied in the Islamic teaching both inside and outside the classroom (Daradjat, et al, 2012: 89-90).

In addition, the source of educators at the school have a different educational background, there are a master and doctoral graduates, both graduates in the country and abroad. This shows that the teachers' intercultural communication competence is very good in terms of awareness of the differences and diversity of students' background so that the cultural and ethnic conflicts can be resolved properly. This is consistent with Bin-Tahir \& Rinantanti (2016: 79) which states that the intercultural competence of a teacher is one of the decisive factors for the successful teaching and learning in multicultural classes.

The pesantren environment also strongly supports the achievement of the implementation of teaching and learning outcomes whereby they all lived in a hostile so as to facilitate the stakeholders and teachers to control and evaluate the students' learning outcomes significantly from their character and behavior inside the boarding schools (Azra, 1999: 5).

The teachers' behavior as a role model greatly influences the students' behavior and be an example in terms of mimicking their speech acts. It is caused by the young age of the students who tend to imitate the actions and styles of people they consider to be an idol. Although there are a contention and undisciplined behavior of some students, it is not caused by the differences of their ethnicity, race, and belief, but it is due to the differences of view and misconceptions the idea that is considered as a natural thing in the growth and development of adolescents' psychological. The students' lives like a prisoner in a dormitory with strict supervision even further strengthen their unity and brotherhood for the same destiny and purpose among them, so that they are no longer concerned about the diversity in culture, race, and ethnicity. From the discussion above, it can be described a model of Islamic teaching implementation in multiculturalism classroom at pesantren schools as in Figure 1 below:

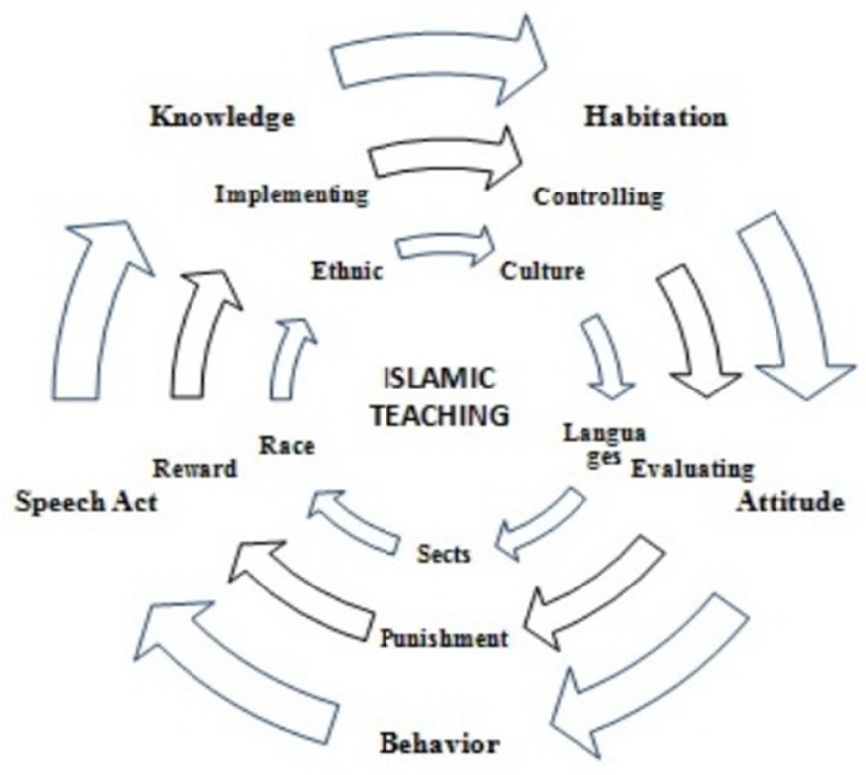

Figure 1. The Implementation of Islamic Teaching Model

Figure 1 shows that the implementation of the Islamic teaching in multicultural classes at boarding schools more emphasis on controlling and evaluation. Those aspects were supported by the strict rules, reward and punishment applied by pesantren. Without the strict reinforcement in monitoring and controlling the implementation, the results of teaching and learning will not affect the students' behavior. The reward and punishment were applied by schools aim to familiarize the students to behave according to Islamic teachings so that it will become a necessity and the demands of the social interaction with the surrounding communities based on the principles of Islam. As the Malay Proverb states that anything could be done because it used to do. This principle is always used as a reference by teachers and stakeholders in implementing the Islamic teachings at pesantren. 


\section{Conclusion}

Based on the results and discussion, it can be concluded that the implementation of the Islamic teaching in multiculturalism classroom at pesantren schools was determined by several factors including the vision and mission of pesantren, the background of teachers, teaching methods, the system of dormitories for students, control, and evaluation. Those factors can be well-implemented due to the reinforcement such as the reward and punishment which was strictly and firmly to support the teachers' control and evaluation. The reinforcement aimed to familiarize the students' behavior in accordance with the Islamic teachings that will continue to take root in their speech acts and attitudes in social interaction with the surrounding community.

\section{Implication of the Study}

The present study aimed at exploring the implementation of Islamic teaching multiculturalism class at pesantren schools in Indonesia. Some implication of the study could be presented as follows:

First, the study contributes to understanding the case of Islamic teaching implementation at pesantren schools as the information and reference to the government, pesantren stakeholder, and further researchers in this field of the study to explore more about the successful of Islamic teaching.

Second, the result of the study is not intended to be generalized to all contexts or schools since the design of this research was qualitative approach and the aim of this study was only to investigate the implementation of Islamic teaching in multiculturalism classroom and the factors affecting the success of the implementation that can be measured the effect of Islamic teaching implementation quantitatively by further researchers.

\section{References}

Azra, A. (1998). Esei-Esei Intelektual Muslim dan Pendidikan Islam. Jakarta: Logos.

Azra, A. (1999). Pendidikan Islam, Tradisi dan Moderisasi Menuju Milenium Baru. Jakarta: Logos.

Bank, J. (Ed), (2001). Handbook of Research on Multicultural Education (2nd ed). Michigan: Jossey-Bass.

Bin Tahir, S. Z. (2011). The Effectiveness of English teaching method at Pesantren IMMIM of Makassar. Jupiter Journal, 9(1), pp. 34-43.

Bin Tahir, S. Z. (2015). The Attitude of Santri and Ustadz toward Multilingual Education at Pesantren. International Journal of Language and Linguistics, 3(4), 210-216. https://doi.org/10.11648/j.ij11.20150304.13

Bin Tahir, S. Z. (2015). Multilingual Behavior of Pesantren IMMIM Students in Makassar. Asian EFL Journal, August 2015, 86, 45-64.

Bin Tahir, S. Z. (2015). Multilingual Education in Pesantren Context. Yogyakarta: Penerbit Deepublish.

Bin Tahir S. Z, \& Rinantanti Y. (2016). Multilingual Lecturers' Competence in English Teaching at the University of Iqra Buru. Asian EFL Journal, 5, 79-92.

Bin Tahir, S. Z. (2017). Multilingual Teaching and Learning at Pesantren Schools in Indonesia. Asian EFL Journal, 89, 74-94.

Cohen, L., Lawrence, M., \& Keith, M. (2007). Research methods in education (6th ed.). USA and Canada: Routledge.

Daradjat, Z, et al. (2012). Ilmu Pendidikan Islam. [Islamic Education Science]. Jakarta: Bumi Aksara.

Daulay, P. (2009). Sejarah Pertumbuhan dan Pembaruan Pendidikan Islam di Indonesia [The History of Islamic Educational Growth in Indonesia]. Jakarta: Kencana Prenada Media Group.

Depag, R. I. (2011). Data statistik jumlah Pondok Pesantren di seluruh Indonesia [The Statistic Data of Pesantrens in Indonesia]. Retrieved 11 March 2014 from http://pendis.kemenag.go.id/file/dokumen/.

Engku, I., \& Zubaidah, S. (2014). Sejarah Pendidikan Islami [The History of Islamic Education]. Bandung; PT Remaja Rosdakarya.

Fadjar, M.A. (1998). Madrasah dan Tantangan Modernitas. Bandung: Mizan.

Gay, L. R., Mills, G., \& Airasian, P. (2006). Educational research: Competencies for analysis and applications (8th ed.). New Jersey: Pearson Prentice Hall.

H.A.R. Tilar. (1998). Beberapa Agenda Reformasi Pendidikan Nasional Dalam Perspektif Abad 21, Cet. I. Magelang: Tera Indonesia. 
Kothari, C. R. (2004). Research methodology, method and technique (2nd ed.). New Delhi: New Age International (P) Ltd.

Madjid, N. (2013). Bilik-Bilik Pesantren; Sebuah Potret Perjalanan. [The Rooms of Pesantren: A Portrait Trip of Pesantren]. Jakarta: Penerbit Dian Rakyat.

Mastuhu, J. (1994). Dinamika Sistem Pendidikan Pesantren: Suatu Kajian tentang Unsur dan Nilai Sistem Pendidikan Pesantren [The Dynamic of Pesantren Education System]. Jakarta: INIS.

Nizar, S. (2013). Sejarah Sosial dan Dinamika Intelektual Pendidikan Islam di Nusantara [Social History and Dynamic of Islamic Intellectual Education in Indonesia]. Jakarta: Kencana Prenada Media Group.

Rehman S and Askari, H. (2010). How Islamic are Islamic Country. Global Economy Journal, Barkeley Electronic Press, 10(3), 1-39. https://doi.org/10.2202/1524-5861.1680.

Tilaar, H.A.R. (2004). Multikulturalisme, tantangan tantangan Global Masa Depan dalam Transformasi Pendidikan Nasional. Jakarta: Grasindo.

Yasmadi, N. M. (2002). Modernisasi Pesantren. Jakarta: Ciputat Press.

\section{Copyrights}

Copyright for this article is retained by the author(s), with first publication rights granted to the journal.

This is an open-access article distributed under the terms and conditions of the Creative Commons Attribution license (http://creativecommons.org/licenses/by/4.0/). 